\title{
External Relations and the EU
}

\author{
Armin Cuyvers
}

\subsection{Introduction}

The area of EU external relations is a complex one. Over time, the E $\mathrm{U}$ has gradually developed more competences to act externally, but the competences of the E U vary significantly over the different areas of external policy. ${ }^{1}$ Institutionally, the area is complex as well. Multiple E $\mathrm{U}$ actors and the Member States all want to exert their influence, crowding the international stage. This 'multiple-actorsyndrome', however, merely reflects one of the fundamental dilemmas of EU external relations: in principle it would be good if the EU could speak with one voice, but in most fields of external relations Member States are simply unwilling to transfer the powers to the $\mathrm{EU}$ that this requires.

In line with the comparative aim of this book, the present Chapter focusses on the development of EU external relations in the early days, especially on the creation of implied external competences where the Treaties did not provide for explicit ones. In addition, it discusses the legal principles developed by the CJEU to ensure that Member States do not undermine the external policies of the EU with their own foreign policy. First, however, this Chapter briefly discusses the institutional landscape in EU foreign affairs, which is still haunted by the ghost of Kissinger. ${ }^{2}$

\section{2 'Who do I call': The Crowded European Stage}

According to EU mythology, Henry Kissinger once complained in exasperation: 'if I want to talk to Europe, who do I call?' Even though he may actually never

1 See also for the major changes in this field after Lisbon P. Van Elsuwege, 'EU External Action after the Collapse of the Pillar Structure: In Search of a New Balance Between Delimitation and Consistency' (2010) 47 CMLRev, 987 .

2 For more general overviews of EU external relations see for example G. De Baere, Constitutional Principles of EU External Relations (OUP, 2008), P. Eeckhout, EU External Relations Law, (OUP, 2011), or B. Van Vooren and R.A. Wessel, EU External Relations Law: Text, Cases and Materials (CUP, 2014). 
have said this, the story survives as it so aptly captures one of the problems of EU external representation. There is no single institution or person that has the general authority to represent the entire EU, such as the Us President or Secretary of State. Instead, multiple actors are usually involved. ${ }^{3}$

To begin with, in many external fields, certainly in the Common Foreign and Security Policy (CFSP), the European Council and especially the Council of Ministers are the central actors, also demonstrating the often intergovernmental character of this field. ${ }^{4}$ Certainly in non-CFSP external relations, however, the Commission also plays an important role in representing the EU externally, for example also in negotiating international agreements on behalf of the EU. ${ }^{5}$ In addition, in areas where the $\mathrm{EU}$ and the Member States share a competence, all 28 Member States may also be active themselves. ${ }^{6}$

The Treaty of Lisbon tried to streamline the external representation of the EU by creating the office of the High Representative of the Union for Foreign Affairs and Security Policy, who is supposed to 'conduct the Union's common foreign and security policy.7 As the High Representative is simultaneously the Vice-President of the Commission for CFSP, the chair of the Foreign Affairs Council and may take part in the work of the European Council, the hope was that this function could unite the external representation of the $\mathrm{EU}$ and silence Kissinger once and for all. At the same time, however, the Treaty of Lisbon also created a permanent President of the European Council, who shall 'at his level and in that capacity, ensure the external representation of the Union on issues concerning its common foreign and security policy.' Similarly, the responsibility of the President of the European Commission to represent the EU externally was not removed, nor was the external role of the rotating presidency of the Council.

An example of the complications that may arise with so many actors was provided when President Obama refused to come to a Summit in Spain in May 2010. Again as EU mythology has it, the President of the European Council, the High Representative, the President of the Commission, the President of the European Parliament, the Member State holding the rotating presidency

3 See also C. Tomuschat, 'Calling Europe by Phone' Guest Editorial 2010 (47) CMLRev, 3.

4 See generally title $\mathrm{v}$ of the TEU. For a general introduction of the different $\mathrm{EU}$ Institutions see EU Chapter 2.

5 See Article 17(1) TEU and Article 118 TFEU.

6 See on this situation also C. Hillion, and P. Koutrakos (eds) Mixed Agreements Revisited (Hart, 2010).

7 Article 18 TEU.

8 Article $15(6)$ TFEU. 
of the Council and several of the heads of State or Government of individual Member States could not agree on protocol, including on the question who would shake Obama's hand first. ${ }^{9}$ Clearly this is only an anecdotal illustration of the underlying problem identified above: the EU has no single institution with the authority and legitimacy to pick up the phone on behalf of the entire EU. As long as that is the case, the EU will need to coordinate and cooperate, and hence cannot be as unified externally as some would like.

\subsection{EU External Competences}

As discussed in EU Chapter 3, the EU is based on the principle of conferral. Consequently, it only has those competences conferred on it by the Member States, also in the field of external relations. ${ }^{10}$ In this regard Article 21 TFEU first spells out the objectives of the EU. Subsequently, Title V of the TEU (CFSP), ${ }^{11}$ and Part V of the TFEU (non-CFSP external policies) provide the EU with most of its explicit external competences to actually realize these objectives. ${ }^{12}$

When the EEC was created in 1957, however, the Community lacked almost all of the explicit external competences it has today. The Treaty of Rome only provided for two explicit external competences: the Common Commercial Policy and the conclusion of Association agreements. ${ }^{13}$ This lack of external competences created a problem, as the (then) Community often had to act externally, already to be able to achieve its internal objectives. In line with its general teleological approach to competences, the CJEU developed the doctrine of implied powers to deal with this lacuna. Three types or categories of implied powers were developed by the CJEU.

The first category of implied powers was created in the seminal case of AETR. This judgment concerned the question if the (then) Community had the competence to sign an external agreement concerning the work of crews of vehicles engaged in international road transport (the AETR agreement). It is relevant to note that the $\mathrm{EU}$ already had adopted legislation on this topic internally, but the Treaty provided no express competence to adopt an agreement on this point externally. The CJEU held that: 
Although it is true that Articles 74 and 75 do not expressly confer on the Community authority to enter into international agreements, nevertheless the bringing into force, on 25 March 1969, of Regulation No. 543/69 of the Council on the harmonization of certain social legislation relating to road transport (oJ L 77, p. 49) necessarily vested in the Community power to enter into any agreements with third countries relating to the subject-matter governed by that regulation.

This grant of power is moreover expressly recognized by Article 3 of the said regulation which prescribes that: "The Community shall enter into any negotiations with third countries which may prove necessary for the purpose of implementing this regulation'.

Since the subject-matter of the AETR falls within the scope of Regulation No. 543/69, the Community has been empowered to negotiate and conclude the agreement in question since the entry into force of the said regulation.

These Community powers exclude the possibility of concurrent powers on the part of Member States, since any steps taken outside the framework of the Community institutions would be incompatible with the unity of the Common Market and the uniform application of Community law. ${ }^{14}$

The use of the internal competence, in other words, had created an (implied) external competence. The CJEU thereby connected the existence and use of an internal competence to the existence of an external competence, greatly expanding the capacity of the (then) Community to act externally.

The second category of implied powers concerns those cases where the internal power to act for the attainment of a specific objective itself necessitates external action. ${ }^{15}$ Some internal market rules, for example, may have an inherently international aspect. ${ }^{16}$

A third 'implied' external competence can be found in Article $35^{2}$ TFEU. The residual competence granted by this provision may also be used for external action where an EU action is necessary to attain a Treaty objective but no explicit of implied power can be found in the Treaties. ${ }^{17}$

14 Case 22/70 AETR [1971] ECR 263, paras. 28-31. Also see Cases 3, 4, and 6/76 Kramer [1976] ECR, 1279 paras. 19-20 and Opinion 1/03 ECLI:EU:C:2006:81, par. 115 .

15 See Opinion 1/76 Laying-up fund [1977] ECR 741, par. 3 as well as Opinion 1/03 ECLI:EU: C:2006:81, par. 115 .

16 In Opinion $1 / 76$ regulating transport on the river Rhine, for instance, could only be achieved by international action as it needed to include non-EU Member States. 
Through these three types of implied powers, the CJEU created a significant capacity for the EU to act externally based on internal competences and legislation already adopted inside the EU. With the Treaty of Lisbon, the extensive and often complex, case law of the CJEU on implied external powers has been codified in Article 216 TFEU. ${ }^{18}$ For the EAC, however, especially the initial case law, linking internal competences to external competences via a logic of unity, coherence and effectiveness, may be most relevant.

\subsection{Sincere Cooperation and the Negative Obligations of Member States}

A last issue that may be relevant to the EAC, considering the fact that the Partner States participate in multiple international and regional bodies, is the obligation of EU Member States not to undermine or frustrate EU external action. The precise obligation of Member States in this regard depends on the nature of the EU external competence at stake.

In areas where the $\mathrm{EU}$ has an exclusive external competence, such as in the Common Commercial Policy (CCP) or the Customs Union, Member States are in principle not allowed to act externally at all, unless they have permission from the EU to do so. ${ }^{19}$ Consequently, where Member States participate in an International Organization, like the G20, and issues are discussed that touch on an exclusive competence of the $\mathrm{EU}$, they are under a legal obligation to act in the interest of the EU rather than to defend their own interests. ${ }^{20}$

In areas where the EU and the Member States share the competence, the principle of pre-emption usually applies. ${ }^{21}$ This means that Member States are no longer allowed to act externally themselves if the $\mathrm{EU}$ has exercised its shared competence. If the EU already has concluded an international agreement on the free movement of workers, for instance on the mutual recognition

18 P. Eeckhout, EU External Relations Law, (OUP, 2011), 112.

19 See also the similar effect of exclusive competences for the Member States internally, as discussed in EU Chapter 3 .

20 F. Amtenbrink, N. Blokker, S. Van den Bogaert, A. Cuyvers, K. Heine, C. Hillion, J. Kantorowicz, H. Lenk and R. Repasi, The European Union's Role in the G2o, (2015) Working paper for the scientific bureau of the European Parliament, 41 and J. Wouters, J. Odermatt and T. Ramopoulos, "The EU in the World of International Organizations: Diplomatic Aspirations, Legal Hurdles and Political Realities", in: Leuven Centre for Global Governance Studies, Working Paper no. 121.

21 See on this point R. Wessel and B. Van Vooren, EU External Relations Law: Text, Cases and Materials (CUP, 2014), 103. 
of diplomas, Member States can no longer act externally on this point. The pre-emptive effect in external relations, however, goes much further. The CJEU has given a very far reaching interpretation to the principle of sincere cooperation, holding that Member States are precluded from all unilateral action that is may adversely affect the realization of a Treaty objective. The $P F O S$ case provides an illustration of just how far this obligation may extend. ${ }^{22}$ In PFOS Sweden wanted to have a certain chemical added to Annex A to the Stockholm Convention on Persistent Organic Pollutants, which fell under a shared competence with the EU. Despite several requests, the Commission and Council had not acted on this point, neither approving nor rejecting Sweden's request. Briefly put, the Council had only started the process of coming to a joint position. The mere fact that the Council had discussed the issue in Council and was adopting a common position, however, already pre-empted Sweden from acting unilaterally. Even the initial stages of undertaking an EU external action, therefore, may pre-empt the right of Member States to act externally on their own.

The duty of sincere cooperation also leads to a general obligation of cooperation on Member States, and an obligation not to frustrate or undermine the effectiveness of EU external actions in any way. Even if Member States are acting in a field where the EU has no competence or has not used its shared competence, therefore, they are under an obligation not to use their own competence in a way that might undermine the effective attainment of EU objectives in another field. ${ }^{23}$ This obligation does not amount to a general obligation for Member States to coordinate all national external actions. ${ }^{24}$ In some cases, however, the duty of sincere cooperation may lead to a positive obligation on Member States to ensure coherence. ${ }^{25}$ Clearly, the extent to which these legal obligations can be enforced in a highly political area is another question, but the main point here is that EU law has developed a set of legal principles and obligations to control the external behaviour of its Member States, even in areas where the EU has only shared or even no external competences.

\footnotetext{
22 Case C-246/o7 Commission v Sweden (PFOS) ECLI:EU:C:2010:203.

23 See for example Case C-266/03, Commission v Luxemburg [2005] ECR I-4805 or Case C-433/03, Commission v Germany [2005] ECR I-6985.

24 See however Article 21(3) TEU on ensuring 'consistency between different areas of its external action and between these and other policies.'

25 See especially C. Hillion, 'Tous pour un, un pour tous! Coherence in the External Relations of the European Union' in: M. Cremona, Developments in EU External Relations Law (oup, 2008), 10.
} 